\title{
Communicating the European Union to Australia: The EU Information Strategy and Its Reception Down Under
}

\author{
Eva Polonska-Kimunguyi \\ Patrick Kimunguyi \\ Monash European and EU Centre \\ Monash University, P.O. Box 197 \\ Caulfield East \\ Victoria 3145, Australia \\ E-mail: Eva.Polonska@monash.edu \\ E-mail: Patrick.Kimunguyi@monash.edu
}

Abstract: The European Union (EU) has become an important global actor in numerous areas. It is an economic giant, a key actor in global trade and trade negotiations. It leads talks on environment and it is the biggest provider of assistance to the developing world. It is the largest contributor to the United Nations budget and its peacekeeping missions are present in all major conflicts. With such prominent global presence, it would seem that when the EU speaks, the world listens.

This paper assesses whether new public communicative spaces are emerging between the European Union and the rest of the world, including Australia. It first argues that supranational developments in the EU have encouraged an important shift in which international political communication is no longer equated with the boundaries of the nation state. It goes on to illustrate how the emergent Euro-polity is developing an important strategy for communication not only with its own Member States and their citizens but also with the world. To test how the new communication environment is received outside the $E U$, encounters of the Australian media with the European Union are analysed. The results tend to confirm the European Union's existing fears of being largely unheard.

Keywords: Australia-EU relations, Australian media and the European Union, EU communication policy 


\section{Introduction}

International political communication - traditionally defined as "the use by national states of communications to influence the politically relevant behaviour of people in other national states" - - has by and large been a process taking place between nation states. The emergence of the European Union (EU), as well as various international organisations on the world stage, has begun to challenge the traditional communication practices among states and created opportunities for new communication practices at supranational level. Caught between intergovernmental cooperation and a possible federalism, the EU's relatively complex nature presents a challenge to the traditional state-centric view of the world, the conduct of international relations, and international communication processes (Schlesinger, 2007).

In Australia specifically, the shift from state-to-state international politics to the Euro-polity level has slowly emerged. As Murray (2006, p. 275) argues, "there is evidence that past assumptions of state-to-state bargaining are being substituted by a new approach as negotiators and businesses come to grips with intensive and extensive regulatory mechanisms and a combination of diverse political and administrative traditions in Europe". At the same time, the EU has been attempting to step up its efforts to communicate itself, its role and actions to its own citizens in Europe, as well as to the outside world. This has been visible in the creation of the EU External Action Service and a new communication policy (European Commission, 2006).

This paper illustrates how the EU is developing its post-Lisbon external communication strategy. Starting from an overview of the relations between the EU and Australia, it assesses whether new public communicative spaces are emerging between the two. To test how the EU's new communication environment is received outside the EU, encounters of the Australian media with the EU are analysed. The results of media content analysis (news articles referencing the EU and its institutions from three leading papers and one television channel) and semistructured face-to-face interviews with key Australian and EU news- and opinionmakers confirm that, despite all the efforts, the EU is not 'selling' itself well on the Australian continent. The paper argues that the EU communication machinery, allegedly different after Lisbon, is not effective and efficient enough to place the

Davison and George (1952) include in the term "international political communication" the propaganda and information activities of most government agencies, and certain aspects of diplomatic communication, but exclude the activities of the press associations and bodies which are interested principally in international education or in religious missionary activities. 
EU prominently on the Australian media agenda. The peculiarities of the mediated communication processes between the EU and Australia are embedded in broader politico-socio-cultural and economic relations, particular political leadership contexts and the wider public attitudes. On the whole it may be Australian political leadership, media, and elites who play a major role in communicating Europe to Australian publics. This article, however, looks at the two-way communication process: from the EU's efforts to make itself visible beyond its borders on one end, to the Australian media and media elites' perceptions of the EU on the other.

\section{Australia and the European Union in historical perspective}

The year 2012 marked the $50^{\text {th }}$ anniversary of Australia-EU relations. In 1962, Australia sent its first ambassador Sir Edwin McCarthy to the then European Community. Although "the modern links between the peoples of Europe and Australia are deep and well-known" (Barroso, 2012), ${ }^{2}$ throughout the $20^{\text {th }}$ century, Australia's relationship with Europe and later the EU was characterised by asymmetry, apathy, antagonism and ambivalence (Stats, 2009). In The Tyranny of Distance, Geoffrey Blainey (1966) depicted Australia as "antipodes [...] drifting, though where they were drifting no one knew". This suggested a dramatic change in Australia's worldview, shifting away from Europe, with "national mindset meandering aimlessly from its old imperial moorings and into the uncharted and unfamiliar waters of the Asia-Pacific" (Curran \& Ward, 2010, p. 64). During World War II, Australian leaders talked about defending the nation as a "bastion of the British-speaking race". However, after the fall of Singapore in 1942, abandoned by the British, Australians became fully aware of the lack of imperial defense at times of foreign invasion. Nevertheless, in the postwar period, Australia remained determined to stay within the British orbit. International turbulences in the period that followed, such as the collapse of the European empires, the rise of Asian nationalism and the development of antiracialism and anti-colonialism were just few external factors that sparked the discussion amongst Australians about their future on the global stage. As James Curran and Stuart Ward (2010) argue, these profound and lasting changes, accompanied by the "decline in the relevance of the 'British race', prompted a genuine outpouring of reflection on the direction of Australian national life".

2 According to the Australian Department of Foreign Affairs and Trade, $70 \%$ of Australians have European ancestry, 30,000 new European migrants come to Australia every year, 1.3 million Europeans visit Australia every year, and 700,000 Australians travel to Europe every year. See DFAT, n.d. 
A period of national identity crisis followed in Australia with leaders and historians trying to figure out "the new spirit of purpose", eventually known as the Australian 'New Nationalism' (Curran \& Ward, 2010, p. 62).

When in the 1960s Britain announced its ambition to join the European Community (which the UK eventually did in 1973), the feeling of abandonment amongst the Australians was overwhelming. "What then shall we put in their [the British] place?" asked Manning Clark, Australia's leading historian (Curran \& Ward, 2010, p. 64).

In his sixth volume of A History of Australia, Clark suggested that the postwar generation of Australians were ill-equipped to deal with the vast array of changes that befell them: "in the second half of the twentieth century Australians lived in a country where neither the historians, the prophets, the poets nor the priests had drawn the maps" (Curran \& Ward, 2010, p. 64). Perhaps this could explain why the unfolding integration on the European continent was received by Australian leaders with confusion and apathy. As Stats argues,

since the signing of the Treaty of Rome in 1957, successive Australian governments have viewed the European integration project with a mixture of suspicion and concern resulting in sometimes apathetic and often antipathetic approaches towards dealing with the novel supranational configuration. (Stats, 2009, p. 2)

The John Howard liberal government of 1997-2006 expressed Australia's most anti-European attitude. Howard explicitly considered it as a "mistake to see all [Australia's] relations with major countries of the Continent through Brussels". He saw Australia as a "victim of the world trading system" and Europe as the "main perpetrator" (Murray, 2007, p. 275; Stats, 2009, p. 10). His preference for traditional state-to-state bilateral relations, however, saw him conduct relations with Europe in bilateral rather than multilateral ways. Australia's most visible "sticking" points with the EU proved to be the Common Agricultural Policy (CAP) and reduction of greenhouse gas emissions, the latter seen by Howard as "not in Australia's national interest" (Murray, 2007, p. 275; Stats, 2009, p. 10). ${ }^{3}$

3 The treatment of its indigenous populations as well as the refugees fundamentally added to the Australia's appalling human rights record. Public opinion turned its back on Howard's nationalistic and populist policies by evicting him after eleven years in office. High infant mortality, unemployment and appalling living conditions amongst Aboriginal communities, did not increase the government popularity. Another catchphrase of Howard, "I don't want people like that here", was to describe asylum seekers, labeled by the media as 'boat people', who allegedly threw their children overboard whilst trying to escape the sinking boat on their way to Australia. The affair was later on proved as largely fabricated by government circles; see Saxton, 2003. 
With the 2007 elections, however, the wind of change blew across Australia and opened the way to improving relations with the EU. The newly elected Kevin Rudd's Labour Government was determined to improve the human rights record. "We say sorry", he declared on his first day as Prime Minister, for the "profound suffering, grief and loss inflicted on Aboriginal people by decades of abuse and mistreatment" (The Age, 2008). The apology, although discussed by earlier governments, had never been delivered. ${ }^{4}$ As the words of the Rudd's government delivered a political breakthrough, the set of policies that followed substantiated the words in action, aiming at improving the health and living conditions of Australia's indigenous people.

The second pillar of Rudd's government was renewed international engagement. Europe returned to the top of the Australian foreign policy agenda. Rudd had an understanding of 'national interest' different to his predecessor. He explained that "acting nationally now requires acting internationally" (Rudd, 2008) and also envisaged a more active role for Australia in global affairs: "A failure to engage with the global community [...] would exclude [Australia] from the chance to shape the global response in ways consistent with [Australia's] national interest" (Rudd, 2008). The new Labour government's first international move was the ratification of the Kyoto Protocol.

An improved human rights record coupled with new international activism opened doors for closer relations with Europe. Rudd pushed for a Framework Agreement with the EU that would replace the existing Joint Declaration, a non-binding statement of common aspirations. The EU quickly became a new foreign policy priority for Australia, extending far beyond trade alone. Rudd was the first Australian PM to schedule talks in Brussels before his official visit to London in 2008. He also proposed the creation of the hotly debated Asia-Pacific Union. Although Kevin Rudd did not finish his term in office and was replaced by his deputy PM, Julia Gillard, the aims of the Australian government did not change Australia's pro-European foreign policy and its willingness for greater cooperation. "There is evidence," Murray (2007, p. 276) commented, of "new ways of thinking about the EU that could dismantle misconceptions about Europe":

There are shared visions regarding the need to confront challenges that go well beyond national boundaries, such as terrorism, and

4 As a party to the UN Charter of Human Rights from the day of its creation in 1947, Australia had had its official "White Australia" policy in place, that aimed at wiping out, or "whitening" the Aboriginal communities. It was largely responsible for the appalling treatment of its indigenous populations as well as refugees and immigrants of non-European descent. 
common concerns with both advancing and managing globalisation. The contemporary dialogue [between the EU and Australia] features new security (including counter-terrorism and defense) and soft security and immigration, as well as educational linkages, in a distinctly different context. (Murray, 2007, p. 276)

Gillard continued Australia's international engagement, making her first scheduled international visit as a PM to Brussels. In October 2010, Australia, together with New Zealand and Russia, became a new member of the Asia-Europe Meeting (ASEM), the joint assembly of ASEAN and EU countries. Whilst in Brussels, Gillard petitioned for a "Special Treaty" between Australia and the EU to be signed in the immediate future. Although high-profile EU officials had visited Australia for thirty years, three high ranking personalities descended on the continent in 2011 alone. Karel de Gucht, the EU Trade Commissioner, José Manuel Barroso, President of the Commission, and baroness Catherine Ashton, chief of the newly created European External Action Service (EEAS), paid historic visits to reclaim Australia as an important partner for the EU. Australia's "pro-active approach to its relationship with the European Union," was welcomed by the Commission's President Barroso:

[W] agree that we must anchor our relationship for the long term, and our challenge is not to transfer our shared interest into shared treaty-level commitments and actions [...] Such an agreement would provide a basis for closer cooperation on a wide range of sectoral policies. (Barroso, 2012)

To the Commission President, the old notions of "Fortress Europe" and "Fortress Australia" have disappeared. "Twenty years of stormy weather", the relationship Australia had with the EU driven by trade (Kenyon, 2012), has recently entered a new stage. It has gradually come to encompass issues such as education and science through to counter-terrorism and also the fight against the proliferation of weapons of mass destruction, and crisis management. "Australia and the European Union share the objectives of enjoying peace, security and trade with Asia" (Barroso, 2012) and these might only be secured by multi-dimensional relationship with both the EU and Australia actively engaged in dialogue. On the opening of the negotiations on the treaty-level Framework Agreement in October 2011, Kevin Rudd, a Foreign Minister in Gillard's government, and Catherine Ashton, EU High Representative, agreed on the first two EU-Australia delegated aid projects. ${ }^{5}$ In this way Australia has

5 In South Sudan, where the EU will deliver food-security assistance on Australia's behalf, and in Fiji, where Australia will deliver a component of the EU's assistance. 
become the first non-European donor with which the EU has established aid cooperation agreements.

\section{Communicating the EU to the outside world}

Yet, the EU has not always been actively engaged in making itself visible and approachable. Its communication capabilities were underdeveloped both inside the EU and with regards to foreign publics. In the aftermath of the constitutional veto in France and the Netherlands in 2005, it became clear that the EU project does not appeal to the European citizens. ${ }^{6}$ The EU Commission embarked on the greatest ever re-design of its communication strategy. As the internal communicative actions of the EU are dictated by the need for democratic legitimacy, effective dialogue with its own citizens seems to be the EU's greatest challenge (Podkalicka \& Shore, 2010, p. 95). The EU strategy for its external communication, according to Michael Karnitschnig, the spokesperson of President Barroso, is motivated by the need to shape and influence the international agenda. He insists that "it's about being seen, it's about influencing the international political discourse" (Karnitschnig, 2011).

Consecutive treaties have sought to establish the EU's external competencies. ${ }^{7}$ The most recent one is the 2007 Lisbon Treaty, which introduced sweeping changes to the scope and organisation of the EU's external relations (Holland, 2012). Firstly, it abandoned the previous division of competences between the EU institutions and its Member States. ${ }^{8}$ Secondly, it spelled out the objectives of the EU foreign policy. They currently include: safeguarding values and fundamental interests; consolidating democracy and human rights; the preservation of

6 As the citizens of France were familiar with the constitution, the familiarity with the text amongst the Dutch population was close to nothing (Eurobarometer, 2005).

7 The Treaty of Rome of 1957 and the Single European Act of 1986 gave the EC responsibilities in the area of external trade. Maastricht Treaty of 1993 presented the Common Foreign and Security Policy with the EU High Representative. Amsterdam Treaty of 1997 incorporated Schengen Agreement into the EU body of law. The EU was put in charge of management of its external borders with an eye on the common immigration policy to be created in the future.

8 According to the Lisbon Treaty, the European Common Foreign and Security Policy (CFSP) is to embrace "all areas of foreign policy and all questions to the Union's security." As noted by scholars, this provision might further complicate decision making in the area of CFSP. It is not clear what still remains in the hands of the MS, and what competencies are transferred to the EU, what role do national foreign ministers play, and what is in the hands of EEAS and its High Representative; see Maythorne \& Peterson, 2010. 
peace and prevention of conflict; fostering sustainable economic, social and environmental development; and improvement of the sustainable management of global natural resources. "As a global actor the European Union stands for a multilateral approach, for an integrated approach to tackle the challenges of globalisation - both the positive sides and the darker sides," explains Michael Karnitschnig:

We are by far the largest trading bloc; we are the largest economic power despite all issues we might have with individual member states and their debt crisis; we are by far the largest donor of international aid with more than half of global aid; we are a trail-blazer when it comes to climate action, we have the most ambitious targets when it comes to curbing emissions and boosting renewable energy. All that gives us a very strong and powerful role on the international scene. (Karnitschnig, 2011)

The Lisbon Treaty established the European External Action Service (EEAS) to promote the EU values and seeks to achieve Common Foreign and Security Policy (CFSP) objectives by multilateral cooperation and good global governance. Also, Kissinger's question, ${ }^{9}$ asked back in the 1970s, was finally given an answer. The Treaty also created the position of High Representative (HR) for Foreign Affairs, a post that links the Commission and the Council. The HR for Foreign Affairs also provides a new "face of Europe", or a clearly identifiable European foreign minister. Wearing her "double hat", Catherine Ashton is to ensure that various policies administered by different EU departments and EU Member States are coherent and articulated in a clear manner. ${ }^{10}$ In regard of the EU strategy for its external communication, Karnitschnig believes that the Lisbon Treaty seeks to achieve unity across different institutions and has streamlined the external relations structure considerably, but it has not totally unified it. He notes that:

We are more or less at cruising speed. When you have such a fundamental treaty change, it takes time, the players need to get accustomed to it, new structures need to be created [...] traditional security and foreign policy is with Ms Ashton, however the Commission holds responsibility in the field of trade, international

9 Henry Kissinger was believed to have said: "If I want to talk to Europe, who do I call? Who is Mr Europe?", see Guérot, 2010.

10 The EU's new diplomatic service designed to "brand" the EU is to "work in cooperation with the individual diplomatic services of the member states [...] by drawing its staff from across three separate sources: former Commission External Relations officials, the Council Secretariat and national foreign affairs ministries" (Holland, 2012). 
economic affairs, climate action, energy, neighbourhood policy, enlargement, sectoral policy, justice and home affairs, migration, etc. (Karnitschnig, 2011)

Yet, despite the Lisbon aspirations to make Europe more coherent and visible to the world, the EU's three major institutions - the Commission, the Council and the Parliament - communicate themselves disjointedly to the European citizens. Moreover, these institutions neglect to focus on audiences beyond the European continent.

On the surface, the EU Commission has several instruments at its disposal to disseminate information. The Europa website is available in all official EU languages, offering a basic overview of the EU policies, institutions, as well as access to the EU body of law. Europe Direct, established after the Dutch and French vetoes, is an information service directly available to citizens via telephone. These two instruments, the EU website and its direct phone information service belong to the so called 'pull media'. They require an active involvement of individuals who are already aware of the existence of the services, seek particular information to suit their needs. It is hard to imagine that this would be the way to attract major interest in EU matters in distant locations in Asia-Pacific.

All three EU institutions run their own newsroom services separately, with the Commission and the Parliament enjoying the biggest share of the EU budget. The efforts of the Parliament target mostly EU Member States (MS). According to Robert Golański (2011), a spokesman to the Parliament's President, around 90 per cent of messages, press releases and footage is distributed to media organisations within MS. The remaining 10 per cent targets Eastern Europe, states that are on the EU waiting list, or struggling to maintain democracy, an issue high on the Parliament's agenda. "We pride ourselves on being at the forefront of fighting for human rights around the world," says Golański. In terms of regional priorities for the Parliament:

We have a special policy towards our neighbourhood, so North Africa to one side, the Middle East to the other. President Buzek has a special interest in North Africa. And the EU being the biggest market $[\ldots]$ or one of the two biggest markets in the world has global consequences. So China is important to us, Russia is important and the US, of course. The EU has developed strong relations with all those parts of the world. (Golański, 2011)

To ensure that messages are sent to citizens and journalists across the EU, the European Parliament's Press Office has embraced new technologies, including 
the Internet and social media. As Richard Freedman of the EUP Press Office explains, this proved successful in raising the knowledge of the dates and the possibility of voting before the 2009 EP elections. The European Parliament Facebook has 165,000 followers - a significant number of followers for a public institution (Rowland, 2011). Social media used by the Parliament also enjoyed political support outside the European continent, for example in Bahrain:

The President of the EU Parliament made several statements about alleged human rights in Bahrain. This led to a huge response from Bahrainis, those both in favour and against their government, but mainly against. Thousands upon thousands supported the President's comments, asked him to act. As a consequence, the Ambassador of Bahrain was called to the Foreign Affairs Committee to explain why so many people were commenting on the Facebook page. In a sense it led to a real development in the political world. (Freedman, 2011)

Europe by Satellite (EbS) is the youngest initiative developed by the EU Council. Available since 1995, it is the Council's television information agency. It does not employ journalists as it distributes unedited raw material, with no analysis or interpretation. Transmitted in original version, audiovisual material is accompanied by the English and French translations and is offered free to non-commercial users worldwide, either by satellite or through a web-based distribution system. As Isabelle Brusselmanns, the chief of the European Council's Press Office explains, it is designed to assist correspondents accredited in Brussels and to equip journalists with sound and images when their own teams are scattered to cover events simultaneously across various EU institutions:

There are lots of official visits here to the Council. They all come with their own media. We jump on those media immediately to tell them how to navigate around, where they can find the footage, how to register and download our material.

The beauty of the system is that it's a completely tapeless procedure, completely digital and easy. You can send a link by email and they can download the footage in their editing software. (Brusselmanns, 2011)

The service has 2,500 registered users, mostly from the countries in South and Eastern Europe, who have less means to send their correspondents to Brussels. They are the EU's closest neighbours, many aspiring to the membership, or covered by the EU Neighbourhood Policy, thus adopting EU legislation 
and learning procedures. China is also a "heavy downloader" of footage, Brusselmanns (2011) claims.

Another audio-visual source of information that, although not EU-funded, is equally European in focus and content is Euronews. It is the longest running pan-European channel with a capacity to reach viewers outside the Continent. It came to life in $1993^{11}$ and limits itself to news and current affairs delivered via cable, digital satellite and terrestrial channels. From its initial broadcast in five languages, the channel has grown to twelve language sections ${ }^{12}$ that employ 370 journalists in Lyon and the newly opened 'European' office in Brussels. ${ }^{13}$ Despite the early predictions that Europeanisation of political, economic and cultural spheres would not be easily reflected on the television screen (Brüske, 1986), the channel continues to expand attracting an audience not only in Europe but well beyond. Its worldwide distribution has nearly doubled in the last five years, and currently reaches 333 million households in 153 countries. In Europe, the Middle East and Africa, the channel's main operational areas, Euronews outpaces its competition in terms of households accessed, and proudly calls itself "Number 1 in Europe" (Euronews Pure, 2011).

Euronews did not begin its operations as an EU broadcaster. However, it is significantly tied to the EU by a grant from the EU Commission to increase EUrelated coverage. The grant, which does not constitute the majority of Euronews revenue, comes at a time when national politics has shifted to Brussels, and national law- and policy-making is no longer exclusively in the hands of national parliaments. ${ }^{14}$ Thus, communicating 'Europe' may now be equivalent to communicating the EU. Presently, around 70 per cent of the news content broadcast by Euronews is Europe-related. During the Summits of the European (EU) heads of states, this figure increases to 80 per cent (Cantone, 2011).

11 Euronews was an initiative of mostly public broadcasters from across and outside the EU: Belgium, Cyprus, Egypt, Finland, France, Greece, Italy, Monaco, Portugal, and Spain. Based in Lyon, France and distributed via cable and satellite, Euronews broadcasts simultaneously in eleven languages.

12 Arabic, English, French, German, Italian, Persian, Polish, Portuguese, Russian, Spanish, Turkish, Ukrainian.

13 The Brussels office is specifically devoted to the coverage of the EU-related events.

14 The term 'Europeanisation' has entered political discourse in Europe, signifying the political, economic, cultural and institutional changes. It is a result of an unavoidable encounter of the 27 now European states with the supranational level. The European Union, increasingly a centre of political economic and legal activities of nation states, is potentially a new supranational form of state (Schlesinger, 2001). 
Euronews is also on a global search for new audiences outside of Europe and spreading the "European message" to the world. ${ }^{15}$ Most of the new developments at Euronews clearly target audiences outside the EU and the European continent. This also coincides with the EU's efforts to establish its common foreign policy. "We're going global because the European Union is going global", explains Sergio Cantone, editor in charge of the Brussels office:

It's about soft power projection. It's about talking to other people, neighbours of Europe, the Arabic people, for example. There are important things happening there at the moment: the Arabic revolutions [...]. We think that there is a growing demand from these countries for support en l'heure de la rigeur from the European countries and from the European Union. (Cantone, 2011)

\section{The EU Delegations}

Despite extensive efforts on the side of the EU, none of the EU communication tools reach Australia directly. Australia does not seem to be on the European Parliament's priority list of "targeted" regions. Sadly, out of over 2,000 journalists accredited with the EUP, not a single Australian media organisation is present (Golański, 2011; see also Freedman, 2011). Likewise, there are no users from Australia based at the EU Council's audio-visual service (Brusselmanns, 2011). It could be, however, that the Council's footage can "sneak" into the Australian media via major news agencies, such as Reuters, or AFP. "They [agencies] take everything and put it in their flow of pictures that they distribute to their clients. So for the client it is Reuters, but in fact it is us." (Karnitschnig, 2011) Although Euronews' recent investments in expansion clearly indicate the channel's global aspirations, its broadcast does not reach Australia. The only news that Australian audiences have access to is via the channel's online content.

Australian media do not seek to reach out to the EU either. In the recent years, the European Parliament has registered decline in the numbers of journalists based in Brussels. Thus, addressing the Australian publics with the "EU

15 The establishment of the Portuguese language section in 1999 was accompanied by the channel's take-off in South America, soon after in North America and Canada. The channel's launch in Asia in 2004 opened the door for broadcasts worldwide (Euronews, 2011). Russian, Arabic, Turkish, Persian, Polish and Ukrainian languages soon followed, together with the new technologies enabling delivery of the channel's message to areas where traditional broadcasting has no reach. 
message" remains in the hands of the EU Delegation in Canberra. Until recently, over 150 delegations represented only the EU Commission in the world. After the introduction of the EEAS, the Delegations are officially representations of the entire EU. They also speak for Member States (Karnitschnig, 2011). Their operations are decentralised and funding for outreach and public diplomacy programs to engage the civil society, local population, local school and universities, and depend on the political priority of the country. As Michael Karnitschnig explains:

It is about specific audience, in specific country, in specific political context. The information activities in an enlargement country, in a candidate country, or a potential candidate country, such as Serbia, Turkey or Croatia, will be much more intense. In a neighbouring country, such as Ukraine, they will be much more multi-faceted than, for instance, in a country that is further away and that is not so much of political priority - a smaller African, or a Latin American country. (Karnitschnig, 2011)

Thus, the EU external priorities are heavily influenced by geography in the first instance: the closer a country is to the EU and the more it inspires to become a member, the more important it becomes to the EU's information activities. External priorities are motivated secondly by the EU's colonial history: closer ties are kept with former colonies of the EU Member States. Finally, attractiveness due to resource abundance also has a strong influence: countries such as Russia, China and the US seem to be more attractive. "We target these individual countries and regions accordingly," says Karnitschnig:

When we talk to the US we want to be seen as an equal partner who can, together with Washington, tackle global issues. When we speak to China, we want to be seen as a very important trading partner, but also as someone pushing for political reforms. When we target Russian audiences, we will of course talk more about energy and societal modernisation. With South-East Asia we talk about trade and economic integration [...] Australia is another piece of cake. (Karnitschnig, 2011)

In Australia, a highly industrialised and developed country, the EU Delegation engages mostly with business, media and political communities (Freedman, 2011). Visits to universities are also more frequent than ever before. Apart from its traditional information disseminating activities, such as feeding the press with EU news, providing own newsletter to its subscribers, the Delegation has also been exploring new means to communicate the EU to the Australian publics. 
One of its initiatives was a hot-air-balloon with the EU flag and logo on it that flew over Canberra in 2008. According to Aneta Podkalicka and Cris Shore (2010, p. 104), "the balloon stunt and the high profile afforded by its posting on YouTube are part of a coordinated diplomatic effort to increase awareness of the EU and its image and external identity in important 'Third Countries"'. Bruno Julien, the former EU Ambassador to Australia and New Zealand, stated that the fact of launching of the EU balloon was a "coronation" of an active year of the EU and the "celebration of a solid relationship between the EU and Australia", as the balloon symbolised

our robust relationship with Australia-not just in trade and investment, but also cooperation in areas such as the environment, regional security, development aid in the Pacific and increasingly in education, research, science and technology. (Podkalicka \& Shore, 2010, p. 104)

Podkalicka and Shore also quote an anonymous informer complaining that the Delegation had paid the balloon company over AUD 100,000 to have their logo displayed during the course of the year: "that's why the Delegation doesn't have any funds for more useful or meaningful activities" (Podkalicka \& Shore, 2010, p. 104). Other means of increasing EU visibility employed by the Delegation include an Ambassador's blog, thematic web pages with games and animations under the category 'Fun'. These, again, like the Europa website and Europe Direct service, would constitute 'pull media', expecting the user to have a-priori knowledge about Europe and come into contact with it though their own volition. The most recent initiative is harnessing joint resources from national embassies of the EU Member States and the EU centres in conversation with the ABC, Australian public service radio.

To see how the EU Delegation engages with Australian media, interviews with senior media editors were conducted by professionals in November 2011. Eight media representatives and one media scholar responded. One question specifically asked the interviewees about their assessment of the information activities of the EU Delegation in Canberra. Although some sceptics, who wish to remain anonymous, thought that the Delegation is all about "these grey men running the show and it's usually pretty dull stuff. They need a bit of charisma" (Media elite representative, 2011), positive comments were not uncommon. According to another media representative, "the Delegation in Canberra is just run superbly. We are fortunate here we've got Ambassador David Daly who is one of the finest ambassadors [...]. He's one of these guys who are fullon, out there, and doing it!" (Media elite representative, 2011) Overall, half of 
the key stakeholders interviewed expressed familiarity and a positive first-hand experience with the Delegation's communication activities.

\section{So what's the picture? The EU through the Australian eyes}

Significantly, out of an impressively broad spectrum of values that the EU promotes on the international arena, none tends to be visible in the Australian media. Brand "Europe", according to Karnitschnig, is about

[p]olitical values, and political systems, such as democracy, human rights, rule of law, the EU's commitment to universal values; civil diplomacy of state building, of reform through engagement; economic diplomacy, the weight of the largest trading bloc, the most densely integrated market with its 500 million extremely wealthy consumers and businesses, EU as a force to be reckoned with in new fields, such as climate change, energy, smart development. (Karnitschnig, 2011)

However, this brand "Europe," in the form the EU imagines itself, is not visible in Australia.

To examine the Australian media images of the EU, the data from a two-phase study was used (a study in 2004-2005, Chaban \& Holland, 2005, and in 2011). Media content from major daily newspapers ${ }^{16}$ and one television program was analysed. Conducted throughout the whole year of 2004, and six months of 2011, content analysis of news on the EU aimed at investigating the daily media visibility and status accorded to the EU and its institutions. It explored the dynamics of interest towards the EU from Australian newsmakers, sources of news about the EU, content characteristics of EU representations in the selected national news media and evaluations assigned to EU images in the media.

Despite the EU being Australia's second largest trade and investment partner, both phases of the study revealed that Australian television news did not consider the EU as the most important partner for their country. Media professionals widely perceived the "rise" of China to have strong implications for the country.

16 The 2004-2005 study compared Australia with New Zealand, Thailand and Korea. It included the coverage of The Australian, Australian Financial Times, Sydney Morning Herald, Melbourne-based Herald Sun and the ABC, 7 o'clock news; the 2011 study looked at ten countries in Asia-Pacific, in Australia it examined the coverage of The Australian, Australian Financial Times, and Melbourne-based Herald Sun and the $A B C, 7$ o'clock news in the 6-month period between $1^{\text {st }}$ January to $30^{\text {th }}$ June. 
The USA and Asia were regarded as having large influence on the regional order in the first Australian study in 2004. The order has changed in 2011, with Asia being seen as of highest importance to Australia. Consequently, with a greater role assigned to the US and China by the mass media, it was of no surprise that the EU was hardly seen as a power to reckon with by Australian media professionals.

Being one of four countries surveyed in 2004-2005, Australia had the highest volume of EU-related news items in print media (171 items per month) and the lowest on television (1.5 items per month). ${ }^{17}$ In 2011, the total of 856 news items were found in the six-month period of monitoring newspapers, and 41 on television. On average, it makes 143 news items per month in the newspapers, and almost 7 on television. This figure is smaller than in the previous study and miniscule when compared to the stories run on the US, China or India in the 2011 study $\left(6,161 ; 3,136\right.$ and 2,885 stories, respectively). ${ }^{18}$

In the 2004-2005 study, a large majority of news stories on the EU in Australia (74\%) were produced as a result of local sources with 16 per cent of news items outsourced from international wires and foreign media (Chaban \& Holland, 2005). It is imperative to note that back in 2004-2005, when the first phase of the 'perceptions' research was conducted in Australia, the EU did not have the communication tools it does today. Hence, it is safe to assume that the EU-led strategy was not the main source of the EU-related media content published or broadcast in Australia. The majority of EU-related television news (61\%) was focused on the EU affairs ('pure EU news', or the events taking place in the $\mathrm{EU}$, related to the EU and without any involvement of Australia in the stories). Another third of all news items dealt with the news on the EU acting abroad, in third countries. Only a small proportion of all television news (5.6\%) was devoted to the 'EU news at home' that put the EU in local, Australian context. The situation in print media was different. The biggest portion of items published by newspapers (39\%) placed the EU in the Australian context, followed by 'pure EU news' (33\%).

Newspapers in the 2004-2005 phases also tended to look at the EU from a minor perspective, with the EU being only alluded to in passing or featured in the story alongside other actors. Australian coverage, in contrast to the three other

17 By comparison, Thai newspapers and television had 74 and 6.8 items per month respectively; New Zealand press published 54 items, television news 2.4 items per month; South Korea 18 items in newspapers and 5.8 on television.

18 On television the difference was less significant: 94 US stories, 26 on China, and 47 on India. 
countries surveyed, treated the EU mainly as a political actor. Eighty per cent of stories featured on television and 64 per cent in newspapers focused on political matters. The most common topics featured the EU's Eastern enlargement, the EU's actions in the Middle East and the EU's relationship with the US. EU anti-terrorist actions and internal security measures were of significant interest, followed by the coverage of the EU in the context of Kyoto Protocol ratification, as well as the EU's dealings with Iran, Russia, Ukraine and its relations with China. With regards to the framing of the EU as an 'economic power', the news in all four countries, including Australia, put the EU's engagement in international trade at the centre of their stories. These stories discussed the EU's role in the World Trade Organisation, EU economic growth and/or decline, the euro and the EU anti-trust business legislation and competition regulations. Australian media also prominently featured topics such as trade agreements and the development of the EU aviation industry (with a focus on different aspects). Predictably, Australia was particularly interested in the EU's agricultural development and its subsidies. The slow-down of the German economy and its consequences for the EU economy as well as EU energy and fishing industries and their impact on Australia were also reported extensively.

The 2011-2012 phase of the study was conducted when the EU had developed its communication instruments and the political leadership in Australia seemed to be more pro-EU than during the earlier research. These tools had no impact on results. The communication tools were utterly invisible as sources in the Australian media under observation. The volume of stories fell, and more importantly, the overall picture of the EU focused on one issue: the sovereign euro debt crisis. The prominent political framing from the first study of 2005 disappeared. The majority of news (over $80 \%$ ) was economic in nature and dealt with state of the economy in Europe and the EU's troubled finances. This time the euro, which was almost non-existent in the first study of 2004, was in the spotlight on a daily basis, due to the euro crisis. This was largely portrayed as a major disaster. Politically-framed reportage that constituted 19 per cent of the overall coverage of the EU depicted the Union disunited over the intervention in Libya. The evaluation of the EU, its policies and institutions by The Australian and Australian Financial Review, the two major Australian dailies, was predominantly negative. The EU officials - the so called "faces of the EU"-were less visible in comparison with the representatives of Europe's national governments. It could be said that, in Australian news media, it was Merkel and Sarkozy who spoke on behalf of the EU while EU leaders were hardly mentioned. 


\section{The EU through the Australian eyes: Media elites' experience}

Interviews with newsmakers in Australia revealed that the journalists and editors have no access to the EU's external communication instruments, such as the EU's Audio-visual Service, and do not receive footage from Europe by Satellite. Euronews, Europe's pan-national broadcaster, has no coverage over the Australian continent. ${ }^{19}$ The only source directly disseminating information about the EU is the EU Delegation in Canberra. Half of the media elites interviewed acknowledged its input into their daily work. Yet, according to the media professionals, the majority of EU news comes from their own sources: media companies, foreign correspondents, or from international wire services, such as Reuters, Bloomberg, Associate Press (AP) and Agence France-Presse (AFP). European national broadcasters, such as $B B C$ World were also used-Australian media outlets see them as reliable. As Mark Baker, national managing editor for Sydney Morning Herald, The Canberra Times and Melbourne-based The Age, admits the three dailies under his management

[h] ave all the resources of the major British and American newspapers. To cover Europe we draw material from those sources. We have a contract both with The Guardian and The Daily Telegraph and we are entitled to republish everything that they publish. They perhaps have a British-centric perspective, except I do think The Guardian is a fine newspaper and I don't know that their analysis and perceptions of Europe are necessarily biased in any particular way simply because they're not in Brussels. (Baker, 2011)

On top of major sources bringing news to Australian through the British or American lens, foreign correspondents "to Europe" from Australian media organisations are also based in London, not Brussels. Therefore their EU news is often refracted through the British lens and is not always direct from the original sources based "on the Continent". For both historical and linguistic reasons, Australian mainstream journalists not only rely predominantly on British sources and also relate to Europe in terms of the UK vs. the Continent. Predictably, the UK matters more, the Continent less. Difficulties in understanding the new integration of Europe are cited as the main reason for the low visibility of and largely negative media attitudes towards the EU. Shane Castleman, head of $A B C$

19 Media elites included journalists and senior editors from $A B C$ television and radio, The Australian national newspaper, Australian Financial Times, and Melbourne-based The Age. 
News Victoria, $A B C$ News, believes that the EU is too complicated to explain in the world limit of a 600 words long story:

I think there's a sense that the Europeans are more or less incapable of organising themselves [...]. We are scratching our heads wondering how to explain everything. For instance, Greece is of particular interest because Melbourne is the third biggest Greek city in the world, we have an extremely high Greek population. But we also look at it and think: 'how the hell did they get into such a mess?' (Castleman, 2011)

Broadcasting media struggle to identify the "faces of Europe". The diversity of voices, as well as statements and messages coming from national and supranational European sources do not make it easy to form a comprehensive picture of the EU. Editors admit that explaining how the EU is organised, what it is responsible for and who makes decisions is a major challenge. According to Michael Rowland, presenter for $A B C 1 / A B C$ News 24,

it is hard to keep explaining that they're [EU] having all of these countless meetings and still no response, no firm action being supplied. It does get pretty frustrating to watch the wheels of international diplomacy turn. (Rowland, 2011)

The financial crisis raging over Europe throughout 2011, kept the EU in the news. "At the moment it's easy" to present a story on the EU, believes Glenn Mumford, markets commentator from the Australian Financial Review, "everything I write they take, so [...] what interests me, and at the moment it is Europe, it gets run" (Mumford, 2011). "It is a fairly hard sell with newspaper editors," added one of senior editors from The Australian who wanted to remain anonymous, "I've really had to make a bit of noise to make sure that we give stories a good run. But we certainly do when the news value warrants it. And certainly this current financial crisis warrants it!" (Media elite representative, 2011) "Unless there's a dramatic event, such as a financial crisis," confirms Mark Baker, national managing editor for Sydney Morning Herald, The Canberra Times and Melbourne-based The Age, "which grabs people's attention over here, it's difficult to make it" (Baker, 2011). To Andrew Cornell, financial news and commentary editor from the Australian Financial Review, it is simple: "if the system is about to collapse, it's not difficult at all!" (Cornell, 2011)

On a more positive note, media elites stressed that the understanding of the EU amongst them is evolving. There is an increase in comparisons of EU and Australian approaches to pressing problems. For example, the Australian press 
looks with interest at how the EU is tackling issues of immigration, terrorist threats and multicultural integration. There are lessons to be learnt on both sides. As explained by Chris Nash, the head of School of Journalism at Monash University, it is the actions the EU engages in and actors it works with, not the EU itself that may be of interest to Australians. His statement is as follows:

It is not important for the Australian audience what Treaty they have recently signed and what changes it proposes. The EU becomes of importance to the Australian media when it is an actor in the events in which Australia is also a participant. When Australia is involved in something that the EU is doing, when their joint action has an impact on people's lives right here [in Australia], then it is 'news', and then it matters. (Nash, 2010)

The 2004-2005 study of EU perceptions in Australia was conducted when John Howard's Coalition government was a ruling alliance. Howard had a very low opinion of the European integration project (Murray, 2002). Media representations of the EU at the time were not good news for the engineers of the European foreign and public relations. It must be acknowledged, however, that the EU in 2004-2005, faced internal legitimacy crises expressed by the veto against the Constitutional Treaty in several Member States. Understandably, the EU did not prioritise communicating itself to the outside world. Thus, the EU's poor visibility in Australian news media and amongst the publics could be partially attributed to the lack of the EU's information capacity.

The second set of data was gathered in 2011 when the political leadership under the Labour government in Australia sought to strengthen relations with the EU (Stats, 2009). The political climate between the two sides was also warmed as the earlier trade disputes had been settled (Kenyon, 2012). Yet, this pro-European orientation of the government was not the catalyst for coverage of the EU by the Australian news media in 2011. The ongoing saga with the crisis in the eurozone overshadowed all other aspects of the European process of integration, both domestically and internationally.

The EU itself is aware of the picture it gets overseas. "In terms of public perceptions, there is a story about decline," notes Karnitschnig and continues that

Europe is seen as an open-air museum. It's going down the drain [...] but let's not forget that the EU is still the wealthiest region in the world, it's the force to be reckoned with! And let's face it: Greece is not even $3 \%$ of the GDP of the euro zone, not even of the EU. So, 
we a have debt problem here because of reckless spending of some governments on whose fingers we should've ticketed off on earlier. We don't have an EU problem here! Communications 101: Perceptions is not a reality! (Karnitschnig, 2011)

Yet, another justification of the bleak picture of the EU in Australian newspapers could be the changing environment of the news media industry. As newspapers merge, cutting staff and outgoings, journalists are required to write more stories for more papers within the same hours and drawing on the same resources. What, they tell us, "sells" the EU is crisis: "[I]t's how newspapers sell. That's why newspapers sell them; that is why people watch TV. Not for good news, but for bad news, more commentary, more comments than actually stories, than facts." (Media elite representative, 2011)

\section{Pulling it all together: can 'Europe' be visible in the Australian media?}

This article has pondered whether the emergence of the European Union has challenged international political communication and the use of national states of communications to influence foreign publics. It has demonstrated that in the case of the EU and Australia the communication processes have only partly moved beyond state-to-state level and into the supranational arena. Australian political leadership has adapted to the new integrated Europe slowly and, only in recent years engaged with it enthusiastically. Amongst the Australian political leadership there has been greater understanding of the EU integration process, its consequences and the benefits Australia can gain by embracing it. The EU officials, too, have recently discovered Australia and its potential for future cooperation. The need for common approaches to pressing problems, such as climate change, terrorism or migration are also emphasised by both Australian political leadership and media stakeholders.

Yet, this re-engagement of Australian and EU political leadership has not been accompanied by the same level of commitment to dialogue by media professionals on both sides. The EU and Australian communication industries simply do not connect. Although Australian media have demonstrated significant interest in supranational Europe, the majority of stories appearing in local newspapers are based on national (mostly British) sources and focus on European nation states. The portrayal of the EU, mediated through national (again, mostly British) perspectives, is largely negative. As Tunstall observed (2011, p. 251), by the 
1990s, Western Europe "had become the world news leader." Countries such as the UK, Germany, France and Spain have had dominated most of the news exports to the world. The BBC, TV France, Deutsche Welle, the British, French and Spanish news agencies dominate the news exchange in Asia, Africa and South America. They outpace the American $C N N$ and the US news agencies in sales to their former colonies and beyond. Why then, is the EU not able to harness the resources at hand to feature prominently in the leading Australian press? Given this potential reach, why is it unable to communicate itself as a whole to the world?

This paper has explored the multiple factors that lie behind the EU's low media visibility and negative profile in Australia. The blame lies on both sides. The Australian media have not sought, or utilised the newly developed EU communication instruments. Also, the complexity of European integration compounds the difficulty for journalists outside Europe to explain the EU in their stories. In many cases, newsmakers' ignorance leads to the perceptions that the EU lacks newsworthiness, stories on the EU are seen as difficult and not attractive to report on. Journalists still see Europe through the prism of their country's past relationship with the UK and this overshadows its relations with the newly integrated Europe. They see Europe as the UK vs. the Continent and have not yet tuned in to the political dialogue their leaders are conducting with the EU.

On the EU's side, too, the communicative efforts lag behind the political agenda in this part of the world. The EU's External Action Service (EEAS) established to promote the EU values abroad has not been supported by a comprehensive communication strategy sufficient to reach the continent Down Under. The EU lacks a single pan-regional 'EU' news agency. Its institutions do not transmit the "European message" to audiences beyond its immediate neighbourhood. The national news agencies and newspapers, on the other hand, are robust, and readily available to Australian journalists. The EU has therefore effectively prevented itself from having any input into Australian stories and images delivered to Australian audience. The Delegation, the only link between the EU institutions and the Australian society at large, may not be sufficient to accommodate the needs of contemporary media industry. Although some of the media professionals interviewed were aware of it, it did not figure as a source of media content over the six months under investigation. Other EU institutions did not feature as information providers either. The EU's achievements were absent from the Australian press; in the era of media commodification and commercialisation it is crisis that sells. Indeed, the most common message reaching Australian audiences is one of European disunity, inefficiency and 
total economic collapse. The EU's successes are not mentioned. In a time when countries are overcoming the past and seeking new partnerships for the so-called "Asian Century," these images of the EU are emphatically not the kind that will yield public support for political dialogue. Who would like to be friends with "Europe in crisis"?

Dr. Patrick Kimunguyi worked as a Lecturer at the Monash European and EU Centre at Monash University, Australia, and as a Researcher at the Global Terrorism Research Centre at the same university. He has been examining terrorism in Europe and East Africa on the ARC Linkage project, 'Radicalisation and De-radicalisation in an Australian Context'. He has also held teaching and research positions at the University of Melbourne and Deakin University, Australia. Patrick was a member of the NCRE's research team working on a transnational project, 'The Visibility of the EU as a Development Actor in South-East Asia, South and East and South Africa and the Pacific', funded by the European Commission. He was also a member of the team examining the external perceptions of the EU in Australia within the framework of a ten-country comparative research project, 'After Lisbon: The EU as an Exporter of Values and Norms through ASEM', supported by the European Commission, Asia-Europe Foundation, the National Centre for Research of Europe and the EU Centre in Singapore. He completed his PhD in Political Science and master's in International Relations at the Institute of International Relations, University of Warsaw.

Dr. Eva Polonska-Kimunguyi worked for the European and EU Centre, Monash University, Australia. She obtained her PhD from the University of Melbourne where she studied media and audio-visual policy of the European Union. Her thesis was titled Culture, Identity and Trade in the European Union: Regulation of Television Content in the Global Era. She received a Master of Arts in Political Science and Journalism from the University of Warsaw, Poland. Dr. Polonska-Kimunguyi also worked as a journalist for Polish national television. She has lectured in media and contemporary European politics, democracy and global politics at Melbourne and Monash universities. Her interests include media, cultural policies and the relationship between media and politics. She has published Culture, Identity and Trade: Regulation of Television Content in the Enlarged European Union (2011) and Transitions Revisited: Central and Eastern Europe Twenty Years after the Soviet Union (2012). 


\section{References}

Baker, M. (2011), Interview with Mark Baker, national managing editor for Sydney Morning Herald, The Canberra Times and The Age, Melbourne, November 2011.

Barroso, J. M. (2011), "Shared Futures: Europe and Australia in the $21^{\text {st }}$ Century", Speech at the Australian National University (2012). Retrieved from http://www. eeas.europa.eu/delegations/australia/documents/press_corner/20111005_03_ en.pdf [accessed 18 May 2012]

$B B C$ (2010), 'Global views of the USA improve,' BBC World Service Poll, 2 April 2010. Retrieved from http://news.bbc.co.uk/1/shared/bsp/hi/pdfs/02_04_08_globalview. pdf [accessed 18 May 2012]

Blainey, G. (1966), Tyranny of Distance: How Distance Shaped Australia's History, Melbourne: Sun Books.

Brüske, H. G. (1986), 'Spiel mit und gegen Grenzen. Profile einer europäischen Fernsehkultur,' in A. Schardt \& H. G. Brüske (eds.) Europa auf dem Bildschirm: Szenarium der europäischen Fernsehwirklichkeit, Bonn: Mainzer Beiträge zur Europäischen Einigung, Band 8.

Brusselmanns, I. (2011), Interview with Isabelle Brusselmanns, audiovisual advisor of Press Office, Council of the European Union, Brussels, July 2011.

Cantone, S. (2011), Interview with Sergio Cantone, editor-in-chief of Euronews, Brussels office, Brussels, July 2011.

Castleman, S. (2011), Interview with Shane Castleman, head of ABC News Victoria, $A B C$ News, Melbourne, November 2011.

Chaban, N. \& Holland, M., eds. (2005), The EU through the Eyes of the Asia-Pacific: Public Perceptions and Media Representations, NCRE Research Series, no. 4.

Clark, M. (1993), A History of Australia, Melbourne: Melbourne University Publishing.

Cornell, A. (2011), Interview with Andrew Cornell, financial news and commentary editor, Australian Financial Review, Melbourne, November 2011.

Curran, J. \& Ward, S. (2010), The Un-Known Nation: Australia after Empire Melbourne: Melbourne University Publishing.

Davison, W. P. \& George, A. L. (1952), 'An outline for the study of international political communications,' Public Opinion Quarterly, vol. 16, no. 4, pp. 501-511.

DFAT (n.d.), Homepage of Australian Government Department of Foreign Affairs and Trade. Retrieved from http://dfat.gov.au/ [accessed Nov 2013]

European Commission (2006), White Paper on a European Communication Policy, COM (2006) 35 Final, Brussels, 1 February 2006.

Euronews Pure (2011), Euronews Media Pack, 2011. Retrieved from http://www. euronews.com/media/download/mediapack/euronews_mediapack_en_2011.pdf [accessed 24 May 2011] 
Freedman, R. (2011), Interview with Richard Freedman, Cabinet of the President, European Parliament, Brussels, July 2011.

Golański, R. (2011), Interview with Robert Golański, spokesperson, Cabinet of the President, European Parliament, Brussels, July 2011.

Guérot, U. (2010), 'New Europe,' European Council on Foreign Relations. Retrieved from http://ecfr.eu/content/entry/commentary_the_new_europe_guerot_east_ magazine [accessed 12 Mar 2011]

Holland, M. (2012), 'The Continued Evolution of the EU as an International Actor,' in No Eutopia: The European Union Today, Deakin: Australian Institute of International Affairs Policy Commentary, no. 12 (April 2012), pp. 43-50.

Karnitschnig, M. (2011), Interview with Michael Karnitschnig, spokesperson to José Manuel Barroso, President of the European Commission, Brussels, July 2011.

Kenyon, D. (2012), 'Australia and the European Union: A Relationship Driven by Trade,' in No Eutopia: The European Union Today, Deakin: Australian Institute of International Affairs Policy Commentary, no. 12 (April 2012), pp. 33-42.

Kenyon, D. \& Lee, D. (2011), 'Australia and Europe,' in J. Cotton \& J. Ravenhill (eds.) Middle Power Dreaming: Australia in World Affairs 2006-2010, Deakin: Australian Institute of International Affairs, Oxford: Oxford University Press, pp. 111-128.

Maythorne, L. \& Peterson, J. (2010), 'New Model Leadership in a New European Union,' Edinburgh Europa Paper Series, Edinburgh: Edinburgh Europa Institute.

Media elite representative (2011), Interview with anonymous media representative, November 2011.

Mumford, G. (2011), Interview with Glenn Mumford, markets commentator, The Australian Financial Review, Sydney, November 2011.

Murray, P. (2002), 'Australian Voices: Some elite reflections on the European Union,' CESAA Review, vol. 29 (October 2002), pp. 5-18.

- (2007), "The EU and Australia: Beyond the 'Tyranny of Distance'?" in P. Anderson \& G. Wiessala (eds.) The European Union and Asia: Reflections and Re-Orientations, Amsterdam: Rodopi, pp. 261-286.

Nash, C. (2010), Interview with Chris Nash, head of School of Journalism, Monash University, Melbourne, October 2010.

Podkalicka, A. \& Shore, C. (2010), 'Communicating Europe? Communication Policy and Cultural Politics', in C. Valentini \& G. Nesti (eds.) Public Communication in the European Union: History, Perspectives and Challenges Cambridge: Cambridge Scholars Publishing, pp. 93-112.

Rowland, M. (2011), Interview with Michael Rowland, editor and presenter, $A B C$ 1/ ABC News 24, November 2011.

Rudd, K. (2008), “Advancing Australia’s Global and Regional Economic Interests," Address to the East Asia Forum in conjunction with the Australian National 
University, 26 March 2008. Retrieved from http:/www.pm.gov.au/ media/ speech/2008/speech_0145.cfm [accessed 21 Jan 2011]

Saxton, A. (2003), “'I certainly don't want people like that here': The discursive construction of 'asylum seekers", in Media International Australia, no. 109 (November 2003), pp. 109-120.

Schlesinger, P. (2007), 'Acosmopolitan temptation,'European Journal of Communication, vol. 22, no. 4, pp. 413-426. http://dx.doi.org/10.1177/0267323107083059

Stats, K. (2007), “The View from Down Under: The Australian News Media's Understanding and Framing of the European Union", Paper presented at the Australian Political Studies Association Annual Conference, Monash University, 24-26 September 2007.

- (2009), "Re-Engaging Europe: Assessing Rudd's European Diplomacy", Conference Paper, Australian Political Studies Association Annual Conference, Sydney, 2009.

The Age (2008), “'Sorry' speech revealed,” 12 February 2008.

Tunstall, J. (2011), 'Europe as World News Leader,' in J. Trappel et al. (eds.) Media in Europe Today, Chicago \& Bristol: Intellect, pp. 251-264. 